\title{
Fear as dread of a God who kills and abuses? About a darker side of a key, but still forgotten biblical motif
}

\begin{tabular}{|c|c|}
\hline \multicolumn{2}{|c|}{ Pieter G.R. de Villiers ${ }^{1}$} \\
\hline \multicolumn{2}{|c|}{$\begin{array}{l}\text { Affiliation: } \\
{ }^{1} \text { Department of New }\end{array}$} \\
\hline \multirow{2}{*}{\multicolumn{2}{|c|}{$\begin{array}{l}\text { Testament, University of the } \\
\text { Free State, South Africa }\end{array}$}} \\
\hline & \\
\hline \multicolumn{2}{|c|}{$\begin{array}{l}\text { Correspondence to: } \\
\text { Pieter de Villiers }\end{array}$} \\
\hline \multicolumn{2}{|c|}{$\begin{array}{l}\text { Email: } \\
\text { pgdevilliers@mweb.co.za }\end{array}$} \\
\hline \multicolumn{2}{|c|}{$\begin{array}{l}\text { Postal address: } \\
109 \text { La Clemence, } \\
\text { Webersvalley Road, } \\
\text { Stellenbosch 7600, } \\
\text { South Africa }\end{array}$} \\
\hline \multicolumn{2}{|c|}{$\begin{array}{l}\text { Received: } 07 \text { June } 2013 \\
\text { Accepted: } 13 \text { Aug. } 2013 \\
\text { Published: } 07 \text { Oct. } 2013\end{array}$} \\
\hline \multicolumn{2}{|c|}{$\begin{array}{l}\text { How to cite this article: } \\
\text { De Villiers, Pieter G.R., 2013, } \\
\text { 'Fear as dread of a God who } \\
\text { kills and abuses? About a } \\
\text { darker side of a key, but still } \\
\text { forgotten biblical motif', } \\
\text { HTS Teologiese Studies/ } \\
\text { Theological Studies 69(1), } \\
\text { Art. \#2018, } 9 \text { pages. } \\
\text { http://dx.doi.org/10.4102/ } \\
\text { hts.v69i1.2018 }\end{array}$} \\
\hline \multicolumn{2}{|c|}{$\begin{array}{l}\text { Note: } \\
\text { Full first name of author } \\
\text { given in the citation for } \\
\text { indexing purposes. }\end{array}$} \\
\hline \multicolumn{2}{|c|}{$\begin{array}{l}\text { Copyright: } \\
\text { (C) 2013. The Authors } \\
\text { Licensee: AOSIS } \\
\text { OpenJournals. This w } \\
\text { is licensed under the } \\
\text { Creative Commons } \\
\text { Attribution License. }\end{array}$} \\
\hline \multicolumn{2}{|l|}{ Read online: } \\
\hline apipg & $\begin{array}{l}\text { Scan this QR } \\
\text { code with your } \\
\text { smart phone or } \\
\text { mobile device } \\
\text { to read online. }\end{array}$ \\
\hline
\end{tabular}

This article investigates the motif of fear of God in biblical texts and contexts by discussing its use to indicate dread and by analysing the implications and consequences of such a reading of this key motif. After a brief overview of research on and contextual information about fear of God, it investigates fear as an intense and extreme human emotion and considers the reason why the motif is used by biblical authors in their discussions of the divine-human relationship, especially in the light of the fact that dread of God implies that God is a threatening force and dangerous power. It then evaluates how biblical authors embed fear within a configuration of thought that contains crucial themes of justice and holiness, without moving beyond this dimension of dread. Finally it investigates some hermeneutical considerations to cope with the challenges that an understanding of fear of God as dread brings with it.

\section{Introduction}

In 2001, Jimmy Loader wrote an essay about the close link between fear and religion in biblical texts with special reference to fear as dread and awe. In one of the rare attempts in contemporary research to move beyond the mere descriptive approach, he reflected on the deeper theological and spiritual values that underpinned the much used and important notion of fear in biblical texts. ${ }^{1}$ He reflected on fear of God's awesome righteousness, which, in mainstream biblical thought, refers to the just punishment of sin. He also evaluated how biblical texts associated fear with divine love and grace which, in turn, generated hope in times of anxiety (Loader 2001:272). ${ }^{2}$

Loader's discussion of fear of God is significant in more than one way. With his contribution he heightens the awareness that biblical texts do not speak simplistically or monolithically about fear of God by pointing out that for Qoheleth, other than is often the case elsewhere in the Bible, humans are not rewarded for their fear of God. The only option left for Qoheleth, Loader (1986:274-275) notices, is to resign to one's fate, clinging to the hope for the occasional moment of joy that may come one's way (Ec 9:7-10). He also analysed how the book of Job regards fear of God as part of Job's suffering rather than indicative of his faith. For Job an exclusively fearsome God would be nothing else but an agent of terror. That this is not the case is revealed only when, in a unique experience, Job discovers the divine care for creation in God's communication with him (Job 38-39). This experience brings him to exclaim in Job $42: 5$ that he has seen God 'whose awesomeness is expressed in [God's] caring for creation' (Loader 2001:275-277). Job has experienced the approachable God, the one who has come near (Loader 1986:277). Fear of God thus has a different character in Job than it has elsewhere. It lacks the conviction that faith as fear of God relates to feelings of trust, hope and love.

In this article I wish to honour Jimmy Loader, an esteemed colleague and friend of many years, with some further thoughts about fear of God in biblical texts. This article will evaluate fear in some biblical texts as dread by discussing and comparing it within the context of human fear as an intense emotion of dread. The article will point out that even where the notion is given a moral and spiritual meaning it often retains its dreadful and even threatening character. It will evaluate how this dimension of dread challenges contemporary readers of the Bible to reflect on its ongoing relevance. But first of all, some brief historical references to the notion and its history of research will be made to locate this notion.

Except for some articles in reference works, the most notable publications, especially monographs, remain that of Otto (1920), ${ }^{3}$ Plath (1962), Becker (1965) and Gray (2003). The present state of affairs in research is, therefore, not only dated, but relatively limited. Little seems to have changed since Balz (1969) entitled his discussion of research on fear of God with the striking title, Furcht vor Gott: 1.On the importance of fear in the Bible, see especially the three earlier studies of Plath (1962), Becker (1965) and Balz (1965).

2.Loader (1986:272), '[o]n the one side there is the aspect of the demanding, strict justice of God and its concomitant motif of God's punishment, which corresponds to the ancient idea of dread or the fear of God.'

3.Smith (2011:206-207) provides a useful, albeit brief overview of Otto's discussion of biblical material. Further also Loader (2001:269). 
Überlegungen zu einem vergessenen Motiv biblischer Theologie. ${ }^{4}$ This is surprising given the implications its widespread use in biblical texts has for religion and theology.

And yet, on closer examination, it may not be that unusual. Except for the fact that fear of God expresses an emotion and as a result drew little interest from scholars ${ }^{5}$ who tended to be more interested in theological and historical scholarship, fear is regarded as a rather unattractive topic in comparison with major more 'theological' themes like justice, reconciliation, ethics, and eschatology. In a recent trend, furthermore, a growing number of scholars are pointing out risks inherent in a religion that is driven by fear of God and by fear of punishment. This development is strengthened by experts in psychology, and psychotherapists who argue that such a religion with a dread or anxiety of the divine may have serious psychological effects and may even lead to violent behaviour. $^{6}$

This apprehension about a key biblical motif is however, not merely a result of modern perceptions. Though Loader (2001:261) provides some seminal information to show how Greeks held fear of the divine in high esteem and even worshipped fear (phobos) as their second most important god, there were growing reservations in antiquity about the role of fear in religion. At an early phase fear of the gods came increasingly under attack in Greek culture. Lucretius wrote his well known De rerum natura because he was concerned about the role of fear in religious life and practices (Van der Horst 2006:128-133). A social-ecological perspective on antiquity shows that such criticism belongs within a situation where the Greeks often had an extreme dread for the wrathful, vindictive manner in which the gods behaved towards human beings, often merely out of jealousy.

As a result of such apprehension, some authors qualified fear of God as a motif by incorporating it within an ethical framework. Authors and philosophers, sensitive to its effects on religion and the psychological servility it promoted, reflected with growing concern on its place in traditional myths about the gods. They regarded the myths as fictitious and naïve attempts to focus on divine punishment in the hereafter in order to scare uninformed and uneducated people to choose for a good life against evil and to inspire a honourable lifestyle (Betz 1983:595). ${ }^{7}$ They argued that it would be superstitious to think that divine beings benevolent in nature - would want to harm human beings and that it would be impious to blame the gods for evil (MacMullen 2006:47). In addition, there were other reasons

4.Fear of God: Reflections on a forgotten motif in biblical theology. For more literature see the doctoral thesis of Engleman (2009), written under supervision of Loader.

5.Kotze (2004:843-863) mentions some reasons and examples. Though emotions in general were sidestepped or treated with distrust by mostly male interpreters of the modern period, other factors that played a role were the overriding concern with theology (and certain theological topoi), its lack of contextuality and the scientific ideal of objectivity.

6.Dirks (1976:13) links the notion of fear with a magical anguish for the supernatural and, consequently regards it as indicative of a servile and immature attitude.

7.The second century author, Pausanias, for example, describes how terrified someone was after consulting the oracle of Tryphonius to such an extent that he lost consciousness. An intense fear was so firmly associated with the Tryphonius oracle that 'losing the ability to laugh became a proverbial expression for consulting oracle that 'losing the ability to laugh became a proverbial expression for consulting
the oracle' (Betz 1983:579). See Dirks (1976:13) on the anxiety of lay people in the the oracle' (Betz 1983:579).
face of hell and damnation. why fear was suspect. Especially philosophers like the Stoics regarded fear in a negative light as an emotion - naturally volatile and untrustworthy - but especially and potentially irrational and cowardly.

This illustrates that already in antiquity a significant number of people expressed reservations about the notion of fear. And yet, despite their reservations, fear retained a seminal place in religious discourse. This in turn, begs the question why biblical authors so often continued to use this notion. To find an answer one needs to reflect on fear as one of the most basic and general of human emotions.

\section{Fear, terror and alarm of others}

The religious discourse of the Bible and biblical times is permeated with fear, horror, anxiety and terror. Israel often experienced intense fear because of continuous threats, war and slaughter by and against enemies. Within Israel the picture is not much different, with mutual strife, intolerance and sometimes brutal infighting between groups and factions.

A close examination reveals that a substantial number of expressions and words in biblical texts are used to describe fear and to moot its various dimensions. Hebrew words like

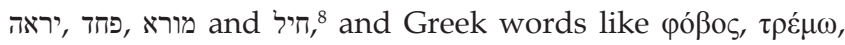

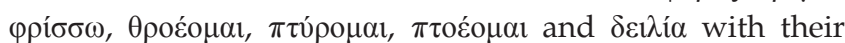
cognates $^{9}$ refer especially to fear of others as enemies and dangerous foes (1 Sm 13:7; 1 Sm 16:4; 1 Sm 23:3; 28:5; Gn 32:7, 45:3; Ex 14:10; 1 Sm 28:21; 2 Sm 4:1; Ps 48:6; Jos 1:9; Is 8:12, 51:12-13; Ps 10:18; Nm 22; Dt 1:17; Jr 26:21; 51:32; Is 8:12; Job 19:29; Mt 14:5; 21:26, 46; Mk 6:20; 9:32, 11:18; Jn 9:22; 19:8; Ac 9:26; Rm 13:3-4, Gl 2:12). It characterised social life. People feared each other in a vicious circle of perpetual violence. A good example is to be found in the actions of the captain and his men in Acts 5:26 who did not use force against the apostles because they were afraid the people might stone them. ${ }^{10}$ Biblical texts connect fear of people with dangerous places, events and animals. There is fear of nature and animals, like, for example, of a lion (Am 3:8), of a storm (Jn 1:5, 10), of thorns (Is 7:23), of the sea (Jn 1:10), of the wind (Mt 14:30; Ac 27:29), of diseases (Dt 28:60) and of calamity and suffering (Job 3:25, 9:28). There is even fear in nature itself: animals have fear of people (Gn 9:2; cf. Jr 51:27). Even the sphere of the supernatural is filled with fear. ${ }^{11}$ Underlying most references to fear as the terror and dread that people have of other persons, objects, situations and nature is the fear of death and destruction. In this sense fear is often an extreme emotion, a matter of life and death.

8.See also Deist (1988:68) who refers to fear in these instances as the psychological response of a person to stronger powers (to fear, to be concerned).

9.For an overview, see Renn (2005:370-373) and Konstan (2006:153) - referring to Zaborewski.

10.Fear of enemies and war is unsurprisingly less prominent in New Testament texts. It does not mean that fear of wars was not present. Such fear is mentioned prominently in an eschatological context in the book of Revelation, but also in passages like Luke 21:9 which speaks of being terrified by news of wars. The terror, as Bovon (2009:177) indicated, expresses an extreme emotion. He translates as 'in Schrecken versetzen, scheu machen.'

11.Note that James 2:19 depicts fear amongst demons as well. 
The phenomenon of fear is complex and comprehensive. Fear affects people on a psychological level when they experience severe fright, anxiety or terror. Louw and Nida (1989:316), thus describe fear as 'a state of severe distress, aroused by intense concern for impending pain, danger, evil, etc., or possibly by the illusion of such circumstances.' The relationship with God is not excluded from such emotions. The dread of God's presence made Job's heart faint and terrified him. ${ }^{12}$ Such fear can be so extreme that it is felt physically and bodily in many different ways. A significant number of physical descriptions for physical fear show how comprehensive it can be. The subject of the fear shudders (Is 19:16), the bones shake, the hair stands on end (Job 4:14-15; Jr 51:27), the face turns pale, the knees knock together and the legs give way (Dn 5:6; Jl 2:6; Nah 2:10; Is 29:22). Such physical expressions speak of extreme dread, once again also in terms of the relationship with God. Psalm 119:120, for example, notes: 'My flesh bristles from dread of You.' One finds in these biblical examples what Aristotle regarded 'as an emotion caused when we face whatever has the power to destroy us or cause us great pain' (Rhet. 1382a 28-29). ${ }^{13}$ Fear then assumes violent or threatening action by an opponent or enemy who is stronger and more powerful and whose pending actions may result in loss of freedom, health, wellbeing and the life of the one being threatened.

Given this background, it is telling as well as challenging that the Judeo-Christian traditions linked their understanding of the divine-human relationship with such a negative, threatening and potentially destructive emotion. Its widespread use therefore provides a good reason to reflect on its place in religion, especially in a time in which its underlying violence and socio-psychological impact raise such apprehension.

\section{Extreme dread of God as the killer}

Despite the above mentioned apprehension, fear firmly retained its place in the Judeo-Christian traditions also in its meaning of dread, particularly in the divine-human relationship. There are enough biblical texts that indicate that fear of God simply meant a dread or anxiety that God, who is seen as the ultimate power, threatens, destroys or kills people. Fear of God reveals similarities with the human experience of fear of others. Though this fear is not about an unfocussed or general feeling of anxiety or dread with a pathological nature, it is terror of the divine, expressed in severe, harsh language. ${ }^{14}$ People are profoundly affected by

12.Job 23:15-17; see also Job 9:34; $13: 21$, Psalm 88:15; Psalm 76:11; Isaiah 8:13 Malachi 1:6; Psalm 22:23; 33:8; Daniel 6:26; Matthew 10:28; 17:6; Luke 1:50; 12:45; 23:40; Acts 10:2, 22, 35; 1 Peter 2:17; Revelation 14:7; 15:4. Exodus 19:9-25 reports the terror that God threatens against those who do not keep their distance (see also Jr 20:7-18; Ps 89:7; Eph 5:21; Phlm 2:12; 1 Pt 1:17; 3:15). The intensity of this encounter is also expressed by the unusual metaphorical language in which it is depicted: The responses to the encounter describe God as a fire that does not burn out.

13.Chambers (2012); Balz (1965:189-190).

14. Some scholars argue against interpreting fear as dread with the argument that fear is used in the sense of respect towards parents (Lv 19:3). Biblical texts can, however, portray parent-child relationships with much violence. Disrespect, contempt of or violence against parents, for example, carry the death penalty (Lv 20:9; Ex 21:17; violence against parents, for example, carry the death penalty (Lv 20:9; Ex 21:17;
Pr 20:20; Dt 27:16; Ex 21:15; Dt 21:18-21). How gruesome this relationship can be Pr 20:20; Dt 27:16; Ex 21:15; Dt 21:18-21). How gruesome this relationship can be
depicted, is illustrated by Proverbs 30:17 which warns disrespectful children that depicted, is illustrated by Proverbs 30:17 which warns disrespectful children that ravens and vultures will peck out and eat their eyes. There is not much respect
or endearment in such portrayals. They rather instil naked fear in those who are, or endearment in such portrayals. They rather instil naked fear
helplessly, subjected to the powerful position of their parents. what the divine says and feel powerless or threatened by it (Ezr 10:3; Is 66:2, 5), by what God does (Gn 42:28; Job 37) or by the judgement of God (Ezk 26:16, 18; 32:10; Ps 90:7). ${ }^{15}$

How threatening the experience of the divine is to some, is clear from established traditions in the Old Testament. Fear as dread is, for example, to be associated with the seminal motif that no one can see God and live (Ex 33:20; see also Jn 1:18; $1 \mathrm{Tm} 6: 15-16)$. In the theophany of 1 Kings 19:1113 Elijah, for example, wrapped his face in his mantle, in a gesture that reminds one of Exodus 3:6 when Moses, having seen the burning bush, also hid his face. The passage explains the symbolic meaning of this physical action: it was because he was afraid to look at God. ${ }^{16}$ The trajectory continues until late in the New Testament period: Moses' fear of God made such an impression that it is mentioned in Acts. Luke makes Stephen recount how Moses trembled at the voice of God from the burning bush (Ac 7:32) and Hebrews 12:21 refers to Moses' intense fear of the presence of God. Lukan texts also refer to the destructive or disastrous outcomes of the encounter with the divine. So dreadful can the fear be after a numinous event that it can cause the human recipient to shun the situation, to be intimidated and even to be repelled by it. The Gerasenes, terrified, beg Jesus to leave their region after his healing of the possessed man because they were seized with great fear (Lk 8:37). For them the dramatic healing of the possessed person by Jesus does not invite them into a similar transformative relationship. On the contrary, they feel so threatened by the action that they want Jesus out of their region.

Other examples of divine actions are much more serious since they describe the killing or intended killing of human beings by God. The divine punishment for a conscious or unconscious transgression is meted out in a most severe manner, or, according to some scholars, even in a fickle or capricious manner. ${ }^{17}$ Well known instances are Exodus 4:24 where Yahweh threatens to kill Moses without any good reason; the punishment of the Israelites after David's census (2 Sm 24:1-17); the attack on Jacob (Gn 31:3; 32:22-32) and on Balaam (Nm 22:20-35) despite the fact that all were carrying out divine instructions. ${ }^{18}$ The killings were not always merely intended, like in Numbers 22:33 where Balaam heard that the Lord would certainly have killed him had the donkey not turned away. In the well known incident about Uzzah who touched the ark of God, Uzzah was killed even though he seems to have done so accidentally. As a result, David was so afraid of the Lord that he refused to take the ark into the city (2 Sm 6:7-9). Even more startling is the Lukan report about Ananias and Sapphira who were killed because they

15.See also the references to the "terrible' God in Nehemiah 1:5; $4: 14 ; 9: 32$ and furthermore, 1 Samuel 11:7; 2 Chronicles 14:14; 17:10; 19:7; 20:29; Job 13:11; 23:15b; 31:23; Psalm 36:1; 119:120, 161; Proverbs 28:14; Isaiah 2:10, 19, 21 Jeremiah 2:19; Hosea 3:5; and Micah 7:17.

16.See the still interesting analysis of Cross (1973:166-167), who draws attention to the close link between the divine kabod [glory] and such strong images as the devouring fire. These images were bound to evoke dread amongst believers.

17.See Brueggemann (1997:359-372) for a discussion of the ambiguous picture of God's character in the Old Testament with reference to divine abuse, deception, inconsistency and contradiction.

18.See Willis (2010:148-149) for an extensive discussion of Exodus 4:24-26. 
lied to the Holy Spirit (Ac 5). The passage refers to great fear amongst the community and all who heard of the extremely harsh actions of God because of their lying (Ac 5:5, 11). ${ }^{19}$ Similar devastating actions that will occur in the end time are described in even greater detail and with extremely vindictive language in the book of Revelation ( $\mathrm{Rv} 18 ; 20: 15$; $21: 8,27 ; 22: 15) .{ }^{20}$ No wonder Hebrews $10: 31$ warns, 'it is a fearful thing to fall into the hands of the living God.' This evidence of fear as experiencing a feeling of being severely threatened by God shows why some readers of the Bible regarded the notion with apprehension and increasing discomfort. It is a notion that suggests hostility, opposition, threat and destruction from the side of God against humans and that evokes intense feelings and emotions of fear and dread.

The reservation about fear becomes even greater when one considers it in terms of its deeper meaning. There is an aspect of fear which is lacking in other emotions and places fear in a category of its own. Nussbaum (2012) singled out fear as the one amongst many emotions that represents a distortion of anxieties that people normally experience. Fear suggests selfishness because it often motivates harsh and violent action against outsiders. Such fear triggers the survival instinct of people which brings them to act in ways that other emotions would not normally let them behave in Not only would this imply that fear of God could be focussed on self-preservation, but it could also cause fear of God to become an instrument of terror against those who represent a threat to the safety of a group or individual because of their God-fearing convictions or actions. Relationships with others become even more destructive when they are influenced by and expressed in actions that are modelled on a vindictive understanding of God's character. This survival instinct of people, based on fear of God, is then legitimised by religious language that is permeated with and driven by fear, and that motivates people to act against others in the name of their religious convictions and their understanding of the character of God. Thus the notion of fear further can elicit receptions of the Bible that characterise God in terms of murderous, hateful vindictiveness which could serve as models of behaviour for followers of God.

Examples of such vindictive attitudes and actions are many. God's punishment motivated early authors to extreme forms of vilification against their opponents. Ancient church historians who singled out Arius as their favourite target, for example, used hideous language to describe how his guts would spill out when he would be punished for his heresy:

Generally God's vengeance was seen as striking at the victim's genitals and bowels, with a confusion of feces and urine in the mouth, it might be, and worms pouring out of disgusting sores and orifices. Such was Arius' fate, arch-heretic. (MacMullen 2006:47)

19.Conzelmann (1987:37) sees this as a miraculous punishment with a parallel in 1 Kings 14:1-18 and Lucian's Philops 19-20.

20.See Luke's violent language to describe divine punishment (Lk 12:32-57) in the Parable of the faithful servant in which the Master of the house punishes misbehaving servants by beating them (see also Lk 12:47, 49-53).
In more recent times, the influential revivalist preacher, Spurgeon (1866:3), for example, reminded his audience in a sermon through a combination of examples how 'God commanded' the slaughter of the Canaanites in Palestine. Without a hint of reflection about the consequences of such an image of a murderous God and the images of ethnic cleansing that can be associated with the collateral actions of Israel, he refers to the 'terrible fact' in biblical texts that God 'justly and rightly' gave a whole population to unmitigated slaughter. He continues to recall in the same passage:

the terrible spectacle of thousands smitten by pestilence at the time of David's numbering of the people. Or of Sennacherib's hosts slain in one night by God's own hand, or even over that direst of all judgments- the destruction of Jerusalem. (Spurgeon 1866:3)

He does not hesitate to see these actions as only fair and right when he continues to quote Deuteronomy 7:10 that God repays and destroys those who hate God. He brings this into the centre of his understanding of God when he refers approvingly and in summary fashion to the title with which Isaiah described God as ' $t$ ] he Lord who renders recompense to His enemies' (Is 66:6). Spurgeon also shows no inclination to question this image of God from a Christian perspective. To the contrary; he underlines its continuing validity by appealing to the New Testament, which he observes, also holds on to this image of God as a God who repays God's enemies with extreme severity and killings. All this is brought together when he links the divine slaughter of humans with the notion of a God who should be feared and with the oftencited verse from the letter to the Hebrews: 'What instances does the Scripture give of what Paul calls "the severity of God", and how true is it that, "it is a fearful thing to fall into the hands of the living God."'21 Such a reception confirms that in many cases, the biblical notion of fear of God is associated with an awareness that God is a killer of masses and has a threatening, terrifying presence amongst human beings who can only fear extermination when they displease God.

\section{Dread of God as the Other}

Biblical texts that evoke receptions which speak of fear of God who kills God's enemies and even God's own people, stand next to and even in tension with other more nuanced references to fear. In these instances fear does not so much draw attention to itself, but points towards and reflects the mysterious, ineffable nature of God as the powerful One. Feelings of dread are described as relating to notions like sovereignty, power, justice, holiness and love. When Pedersen (1959:626) writes that 'Yahweh can claim to be feared, because it is a recognition of his greatness' (Loader 2001:269), it is this 'greatness' that deserves emphasis and more reflection in evaluating fear of God as a motif.

The greatness is clear from the intense emotions that people experience when they encounter God. The subject realises with great fear that his or her experience is different from other, ordinary human experiences. The first response of Jacob to his dream of a ladder that reaches into heaven, is 21.My italics. Spurgeon (1866:3). 
that 'he was afraid' (Gn 28:17) despite, or even because it was a mystical moment about an incident in which the heavenly sphere is involved. Luke also expresses the terrifying, even violent nature of Paul's numinous encounter on the road to Damascus with the remark that after a light from heaven flashed around him, he was flung to the ground by its fearsome impact, even though Paul responded by addressing the divine as the 'Lord' (Ac 9:3-4; 22:7), revealing his awareness of the mystical nature of his vision. Such descriptions reflect a recognition and awareness of human beings that the encounter reveals the divine as being completely different from their own existence.

This intersection between the divine and human spheres and forms of existence caused dread and shock because of the otherness of God, but even more so because of the greatness and power of this otherness and the traumatising experience of realising one's own nothingness. This insight is confirmed by the noteworthy fact that fear is regarded as having a passive, receiving character. Biblical texts portray fear as an acute emotion that people experience as a result of an action that comes to them unexpectedly and powerfully from outside themselves. With the anthropomorphic language of fear, the power, the otherness and the ineffability of what are being experienced is expressed. The actions and character of God, felt to be so different and powerful that it defies all human categories and experiences (Otto 1920:8-12), create feelings of anxiety, shock and terror.

This is why fear is expressed as a configuration of thought that comprises symbolic images of light, fire and darkness and is linked with fearful physical responses. Fear of God is portrayed through these symbolic images as an experience that reminds one of human responses to natural disasters and dangerous threats. Earthquakes, storm winds, fire, smoke and other threatening images are used to express the experience of encountering God. People stood 'at a distance $^{\prime 22}$ when Moses physically ascended the mountain and drew near 'to the thick darkness where God was' (Ex 20:21). According to Exodus 19:18 the mountain was covered in smoke and the Lord descend upon it in fire. As a result of such a numinous encounter with the divine, the skin of Moses' face transformed physically and shone so that Aaron and the Israelites were afraid to come near him (Ex 34:2930). The same configuration is to be detected in the Gospel of Matthew about the transfiguration of Jesus. The mystical event is located also physically on a high mountain (Mt 17:1) and the physical transformation that an encounter with the divine causes, is spelt out when it is said that the face of Jesus shone like the sun. When the nature of the encounter is made clear through the description of the divine proclamation about Jesus as the Son of God, it does not change the situation: the disciples fell face down to the ground in terror (Mt 17:6). ${ }^{23}$

22.Loader (2001) articulates the ineffability (job) and unapproachability of God (Qohelet and Job) well.

23.In Acts 3:13 Luke narrates how the apostles were all together after they performed many signs and wonders, but none of the people dared to approach them. Johnson $(1992: 95)$ remarks, '[t]he apostles appear as numinous figures, and like the mysterium tremendum et fascinans, they both repel and attract.'
These examples illustrate that fear is about an experience of the Other who powerfully transcends human existence and language. It is about dread and shock at a divine initiative that can be so intense and even violent, that it makes people fear for their lives. The Other is not only difficult to fathom and to describe in human language, but is also dangerous to encounter. It is safer to keep one's distance. In this sense fear of God displays a partial, but significant overlap with human fear as an intense emotion of being threatened. ${ }^{24}$ It is also about fear for oneself in the presence of such great power.

\section{Dread of God as the Pure}

That God is a fearsome God who is the complete Other and dangerous to encounter, also has to do with the divine being pure and without evil and with God's character standing in total contrast to the sinful human condition. This pureness is expressed especially with motifs like righteousness and holiness. Though one should be wary of glossing over farreaching different and even rivalling perspectives on the link of fear with righteousness and holiness (cf. Loader 2001:11), there are some characteristic insights or traditions that remain constant.

In general the Bible presents God as the One who has extraordinary qualities of righteousness and holiness. ${ }^{25}$ Fear of God is closely linked with divine holiness. The link between fear and holiness was discussed above when the fear of David after the incident with Uzzah took place, was mentioned. ${ }^{26}$ Other examples confirm that divine holiness instils fear in humans. In Isaiah 6 the prophet experiences with extreme fear the powerful glory of the divine with feelings of devastation and ruin (Is 6:5). In his encounter with God, Isaiah realises that his human state is flawed and defiled. There is also the narrative about the fear and trembling of Ezra and those who feared the word of God, when they heard about the intermarriage of some. The faithlessness of their compatriots defiled the 'holy race' (Ezr 9:2-3).

Of special relevance for the motif of fear as dread is, however, divine righteousness which is often ${ }^{27}$ linked with it, especially where biblical texts warn of frightful judgement of improper behaviour, irreverence and selfishness (Mt 5:29-30, 18:8-9; Gl 6:7-8). Evil is at work where there is no fear of God. Abraham expects to be killed because there is no fear of God in Gerar (Gn 20:11). In his extensive discussion of the human condition at the beginning of the letter to Romans, Paul also ascribes its deformity to the absence of fear of God (Rm 3:18; quoting Ps 36:1) and notes that for this deformity and sin the whole world will be held accountable before God

24.This fear of God is intensified when one realises that God acts with a sovereignty and freedom. For the latter, see Brueggemann (1994:718-720).

25. Holiness is considered by Waaijman (2002:320-324) as one of four key words in the Bible. His discussion shows how closely this concept is linked with righteousness. Both righteousness and holiness are key topoi in the genre of both Old and New Testament theologies.

26.John also fell at the feet of the One like a Son of Man after his vision (Rv 1:17), as if dead.

27.This is, for example, especially true of texts that reflect a Deuteronomistic theology. See Loader (2001:271). 
(Rm 3:19). ${ }^{28}$ The divine judgement is therefore not arbitrary, but is directed at evil (Pr 8:13). The book of Revelation has, next to its message of salvation and as second other major theme, an extraordinary focus on judgement as punishment of the evil opponents of God in heaven and on earth. The witness of the faith community is closely related to fear of God, as is indicated by the first call of the angel in Revelation 14:7 with its call to fear God. Revelation 15:9 asks 'who will not fear God?' and in Revelation 19:5 the faith community as 'servants' is described as those who fear God. In Daniel 6:26-27 the decision of Darius that all in the kingdom must fear God is linked with a long description of the powerful deeds of God. Fear of God aims at bringing people to obey God's demands for this life.

References to the divine righteousness remind people not to act like those humans of biblical texts who lived sinfully in total lack of fear of God. As a result of the divine judgement, they themselves paid a high price in terms of loss of their land, homes and religious forms (Loader 2001:270, 272). They need to be reminded that even the people of God will come under judgement and be removed from the divine presence should they disobey God's righteous demands. Fear of God, therefore, means remaining conscious of the implications and consequences of divine purity for people's attitudes and behaviour, and the need to seek purity for one's own life.

And yet, the ethical nature ascribed to fear of God through this close link with righteousness, does not take away that descriptions of this judgement often have an extraordinarily severe, and by times even an immoral nature. Loader (2001:272) referred to the 'demanding, strict justice of God' to underline the seriousness with which it is regarded in biblical texts. That God's judgement is so serious that it scares people is indeed illustrated by the cry of the Psalmist, 'my flesh trembleth for fear of thee; and I am afraid of thy judgements' (Ps 119:120). One cannot miss, however, the graphic nature of warnings that wish to instil dread of judgement. Matthew (10:28) calls his community to perseverance by quoting the warning of Jesus that believers should not fear people who can destroy the body, but only God who can destroy both body and soul in hell. The picture of God is life-threatening: it is about divine extermination even of those who do not remain faithful. Matthew's Gospel repeatedly describes the dreadful consequences of eschatological judgement in graphic, physical terms, revealing an underlying threatening image of a God who mercilessly and eternally punishes opponents once the day of reckoning has come. It is particularly evident in the images of weeping and gnashing of teeth of those who will be judged and who will be thrown into outer darkness (Mt 8:12; 22:12-13) or into a fiery furnace (Mt 13:41-42; 13:49-50; 24:41-51 \& 25:14-30; see Lk 13:28).

Though these references show that God does not act in an arbitrary or capricious manner against people in so far as divine judgement is a response to evil, divine judgement

28.The parable of the widow in Luke 18:1-8 describes the unjust judge as one who did not fear God. The judge finally renders justice to her, reiterating that he does so not out of fear for God but out of fear that she will attack him (Lk 18:5). sometimes is described in such a way as to instil extreme terror and dread in a rather vengeful manner. One can counter reservations about the vindictive nature of such language with the argument that extreme judgement reflects the terror and horror of totalitarian evil that absolutises and even deifies itself as the solution to evil. Ausschwitz, Hieroshima and Rwanda exemplify to their victims similar forms of evil that elicited the extreme anger of the author of Revelation about the great city that continues the murderous disregard for human life of evil forces in the history of the world (Rv 17-18; 11:8). These cities, like Rome at that stage, are named as Sodom, Egypt and Jerusalem. They represent utter forms of depravity in the guise of goodness. They oppose everything that represents life created and nurtured by the living God ( $\operatorname{Rv} 14: 7) .{ }^{29}$ Such prophetic anger, expressed in vindictive, vengeful language would then indicate how precious creation and human life is and that no one has the right to destroy or abuse it. ${ }^{30}$

The challenge of such a position lies in both its theological implications and its unintended consequences. Dreading God's future judgement because it represents complete annihilation, begs the questions how such divine violence would relate to the alternative suggested in Revelation 21:24 that the nations of the world, previously under severe judgement in the book, have a place in God's future. Such dread further provides an opportunity for abuse and terror when it is read literally. History reveals that victims of abusers often became the abusers of others once they are in a position of power. The faith community as the abused minority who suffered the consequences of their faith in the 1st century CE would in the following centuries use their acquired power of later times to abuse and kill others, often claiming divine sanction for their actions. The evils of the crusades, of the 20th century wars, holocaust, nuclear attacks and racism, were perpetrated in so-called advanced and even highly developed Christian societies and supported by faith communities. Biblical language, taken literally, played a seminal role and offered seemingly perfect models for othering and eliminating those outside their communities or ecclesiastical traditions. If one fears a vindictive God, it is but a little step to vengeful actions in the name of that God, especially when one is driven by the dread of divine punishment for disobeying instructions to distance oneself, oppose the other and retaliate in kind to their perceived injustices ( $\operatorname{Rv} 18: 4-6)$.

In summary then, fear in a way points ultimately to the complete other, shocking nature of God which makes people aware who they really are and what the consequences of their human condition are. Motifs like fear, holiness and righteousness reveal the need to be transformed into a lifestyle that reflects the pure, life-creating character of God. And yet, one cannot escape the impression that in some biblical pronouncements and texts these motifs by times

29.See De Villiers (2002a, 2002b) for a discussion of persecution in Revelation by evil forces who claim to be divine and to be doing good.

30.See De Villiers (2012a:201-225, 2012b:247-273) for an extensive discussion of this issue. Also De Villiers (2009) for later receptions of Revelation in the Byzantine era when the violent character of the book became controversial. 
function in a more destructive than transformative manner. In their coercive and violent character they remind one of how Brueggemann (1997) concluded his remarks on Jeremiah 20:7 and Jeremiah's experience of the relationship with God:

One gets the impression from this lean but powerful utterance that Yahweh is, on occasion, an unprincipled bully who will coerce, manipulate, and exploit in order to have Yahweh's own way. (p. 362)

One needs to be cognisant of biblical verses that speak of fear of God in such a violent way - even where righteousness and holiness are mentioned - that they create space for violence and abuse. The connection with righteousness and holiness guarantees little. The challenge is rather to discover how they function in the religious discourse together with fear. To address this challenge, it is necessary to be cognisant of the darker side of these terms and weigh them in terms of the biblical message as a whole. There are other parts of the biblical proclamation that can make readers aware of the need to recognise and deconstruct this darker side, as shall be discussed briefly now.

\section{When fear pares with compassion}

The biblical portrait of God's character and behaviour by times evokes emotions of extreme anxiety. To some extent one can understand that an encounter with the divine can be a threatening experience. Fear of God serves to underline that faith finds its beginnings in the divine initiative that comes to human beings from outside themselves to transform them into a faith community that lives in an intimate relationship with God. This encounter and relationship is a dreadful experience of the Righteous and Holy One who purifies and empowers. Purifying an existing lifestyle and situation of evil can be traumatic and fearsome. This is also true of the life in faith. As Loader (2001) pointed out in his article, the ongoing spiritual journey in a context of evil can be equally painful and fearsome (Job and Qoheleth). Human nature tends to underestimate the consequences of the relationship and of one's own nothingness, unrighteousness and impurity. Emphasising fear of God reflects an awareness, that one should overcome this state of sin to live as pure, righteous and holy as the One who calls and empowers. Where this does not happen, the consequences will be severe and disastrous. Stressing the severity of compromising the otherness, righteousness and holiness of God in such a context makes sense even if this emphasis can be experienced as threatening and severe. The more so in contexts of extreme evil that presents itself as good and even divine. Such an emphasis serves to warn perpetrators of the dire consequences of their actions, but even more so, it draws attention to how violating their behaviour is experienced by their victims. Fear of God is invaluable in drawing attention to the nature and consequences of evil. It warns the perpetrators, but is also succours and reinforces the symbolic universe of believers as those who experience oppression and who need to be supported in their opposition to evil.

Biblical texts offer descriptions that reflect this process of purification and propose spiritual exercises that promote perseverance amidst hardship and fear. Many of these texts, however, lack the negativity and destructive nature of extreme feelings of dread. They link the intersection of the divine with the human in a way that is not less fearsome, but that motivates or inspires more than that it threatens. That is one reason why contemporary translations have developed a vocabulary that avoids a notion like fear and reflects such terms as awe and reverence. Translators point out that biblical texts filled the notion of fear with semantic contents that remind one of honour or respect that is paid to those who have a higher status. ${ }^{31}$ Fear then reflects social conventions according to which people of note are treated with reverence, amazement, respect and even obedience. ${ }^{32}$ Whilst fear as dread could point to retaliation, vengeance and anxiety, awe suggests intimacy, attraction and closeness to the divine that include respect, reverence and honour.

Loader (2001:267-270) pointed out that fear in the sense of awe is found especially in Deuteronomistic traditions and in the Psalms. ${ }^{33}$ The New Testament provides other examples, amongst which the Lukan texts are perhaps the most striking. After the healing of the paralysed person (Lk 5:17-26) and after the resurrection of the son of a widow in Nain (Lk 7:1117), Luke reports that onlookers were filled with fear. They stand in awe especially because Jesus forgave the paralysed person his sins which also restores him physically and thus holistically to a new existence (Lk 5:26). ${ }^{34}$ In the resurrection of the widow's son, Luke again underlines the awe of the people for the extraordinary compassion of Jesus who consoled the destitute woman and resurrected her son (v. 15). The people respond with fear or awe. As a sign of their experience of this as a numinous event, they glorify God (Lk 7:16). The description of Jesus saving the woman and her son, which reveals Luke's theology of compassion for the needy (Bovon 2002:273, 275) conveys the message that in restoring happiness to the weeping mother of the young man, Jesus is recognised as the powerful Lord of life and death who reunites mother and son (Lk 17:15). The awesome touch of the divine establishes a 'new, redeemed relationship between parents and children' (Bovon 2002:274), but also points towards a general restoration, namely, that God visited God's people (Lk 17:16). The awe of the onlookers marvels at the divine compassion that seeks to establish an intimate relationship of God with God's people. ${ }^{35}$ It transcends their human frame of reference and comes to them as a powerful, overwhelming bolt out of the blue.

The references in Luke's texts connect fear especially with compassion, and for that matter, with love as the divine 31.Louw and Nida (1989:734-736).

32.Deist (1988:125) points out in several pages that fear means awe, honour or respect, to obey in many prophetic books (often without the connotation of fear) See also Hosea 9:15-17; Isaiah 25:3; Micah 7:17; Zephaniah 3:7; Jeremiah 5:22 Deuteronomy $5: 29$. It is often used in a covenant context so that in the prophetic literature the term indicates covenantal obedience (Jr 3:8; 5:24; 26:19; 32:39; 44:10; Hs 10:3; Zph 3:7; Hg 1:12; MI 2:5).

33.Loader (2001:267) concurs with Pfeiffer that this idea is so central that it is the oldest description in the Bible of religion as such.

34.This is shown by the prominent place of the discussion between Jesus and the Pharisees about forgiveness (Lk 5:21-24).

35.The healing of the paralytic in Acts $3: 1-26$ by Peter and John, as well as the overpowering of the sons of Sceva in Acts 19:11-20 display a similar pattern. 
reaching out to humanity in a self-giving action. It is a fear that reflects the awe of God, who truly cares for God's people. This Lukan presentation of fear as awe before the numinous events in their midst is not completely unexpected. Though the God of Israel was a fearsome God, God remained associated with love and trust, as Loader (2001) stresses. A key verse in this regard is Deuteronomy 10:12-22. It speaks of events after the giving of the Ten Commandments to Moses. The passage is permeated by powerful, loving motifs. God as owner of heaven and earth must be feared as a powerful God who has done great and terrible things. Israel is to fear the Lord in order to be able to walk in God's ways, to love, serve and obey the divine commandments. God who loves Israel is not partial, but just and loving. Believers respond to a God who is a God of love, compassion and kindness. ${ }^{36}$

Finally, Luke is consistent in the way in which he links fear of God also with the life of the later faith community. Acts 2:43 and 9:31, both of which are of special relevance to the book as a whole and for Luke's theology, describe the nature and actions of the early community. Fear of God is a key characteristic of the community's identity. After their baptism, the believers devoted themselves to the apostolic teaching and fellowship, the breaking of bread and prayers (Ac 2:41-42). Acts 2:43 then speaks of their fear, that is also trembling and terror, which came upon every soul in the light of divine intervention in the life of the community. ${ }^{37}$ Luke links fear in this instance with powerful, fearsome wonders and signs done by the apostles (cf. Ac 2:19-20), ${ }^{38}$ but their fear is more than fear of the awesome power of God. It is also an ongoing attitude that characterises the community in their continuing spiritual journey and existence. This is clear from the imperfect tense that Luke uses to indicate reverence for God that remained in them. ${ }^{39}$ Awe of God is part of a transformed lifestyle, brought about by the overwhelming and powerful touch of God through the apostolic ministry, but which continues as they remain in fellowship and community of possessions and care for the needy. Here too, awe of God is linked to a community with and compassion for others.

All this is stressed by the outreach of the faith community to include others. In another summarising section in Acts 9:31 Luke prepares his readers for the integration of gentile groups into the faith community that is described in the last half of Acts. In this strategic verse, he again explains the nature of the church. As the church continues to grow in

36.The suggestion of Loader (2001:266) that Israel should have no fear in, nor for the world, is grounded in the fact that God is there for God's people, is an indication that it is ultimately their understanding of God's character that qualifies the biblical pronouncements on fear of God. It is the divine presence which determines the nature of fear. He therefore aptly speaks of 'a fundamental thought pattern in Deutero-Isaiah and John's first letter that the element that drives off fear, lies in the encounter with God.'

37. Some text editions link the fear with everybody in Jerusalem, others only with the believers. Pesch (1986:131) favours the latter reading.

38.Jervell (1998:155) does not see any coherence of the fear with the preceding verses. He explains it as typical of a summary.

39.Chambers (2012:71); see also Barrett (1998:166). It should be translated as fear lay upon and not as fear came upon (as at 5:5, 11). See also Genesis 35:5; Psalm 104 (105):38; 1 QH 4:26.
Judea, Galilee and Samaria, ${ }^{40}$ the church lives in peace, was built up and walked in the fear of the Lord and the comfort of the Holy Spirit. In this case fear refers to the ongoing reverence for God, in the Old Testament sense of the word (Barrett 1998:166). The faithful are strikingly described as those walking in the fear of God. Awe of God is spelt out as a major aspect of the spiritual journey of the early church and as a reason for its growth (Jervell 1998:294). Luke goes out of his way to stress the inclusive nature of the church, taking over an existing description that uses fear of God to indicate the religious identity of non-Jews who associated themselves with the religious beliefs of Judaism, who lived according to the $\operatorname{law}^{41}$ and who shared Jewish worship of God without officially becoming Jews. ${ }^{42}$ In Acts 10:2 Cornelius is described

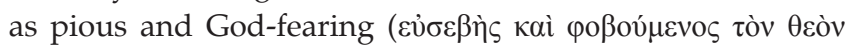

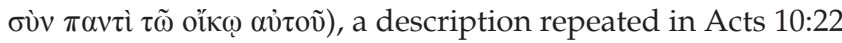

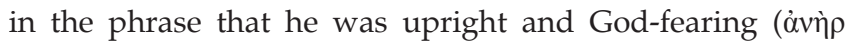

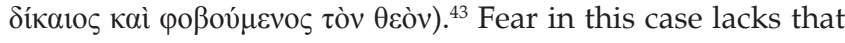
dimension of self-preservation at the cost of others which Nussbaum (2012) regards as its most base characteristic.

And yet, all is not that clear. Luke too has his moments of darkness. Here too, it must be remembered what was mentioned earlier about Luke's understanding of fear. His compassionate and reverential language and thoughts stand in tension with other parts in Luke's texts. It is, after all, Luke who included graphic descriptions of divine violence at the end of time and used extremely violent language in the parables to instil fear in his readers. In Acts he found the story of Ananias and Sapphira important enough to include them in his description of the life experience of the early faith community.

The reader of the Bible who notes this darker side of the Bible in its discussion of fear, needs to discern to what extent such pronouncements do justice to the compassionate, loving God before whom God's children stand and live in awe and to what extent they create space for abusing and even killing others.

\section{Conclusion}

When God touches someone, it is a fearful moment and it sets in motion a lifelong journey of fear. This fear is described by Waaijman (2002:316-319) as a key notion in spirituality - one of only four (the others being holiness, mercy and perfection). He, like many others, is aware how fear of God

40.Conzelmann (1987:23): "The summary interrupts the progress of the account and gives the reader some information about the nature of the earliest church.'

41.This remark also points towards the other established meaning of fear as obedience to the law. This is made clear when Peter speaks to him and his household and links God-fearers with a righteous lifestyle (Ac 10:35). In Acts 10:35 the one who fears is not linked to a specific group. Jews are, therefore, also included (Barrett 1998:519).

42.Cornelius's baptism was severely criticised by the circumcision party in Jerusalem because he was uncircumcised (Ac 11:2-3; also 10:28). In Acts 11:28 this party praised God for the gift to the Gentiles of repentance unto life. Luke, however, underlines the law-abiding attitude of Cornelius. The giving of alms is an indication of his obedience and thus of his adherence to the law.

43. One of Cornelius's soldiers is also described as devout (Ac 10:7). Jervell (1998:307) reads Síkaloc as living in compliance to the law and refers to Luke $1: 6 ; 2: 25$ 23:50. He distinguishes (p. 352) the God-fearers as a group from the Jews as the 23:50. He distinguishes (p. 352) the God-fearers as a group from the Jews as the
second group in the synagogue, as is indeed indicated in Acts 13:16, 26. See Tyson (1999:91-109) for a full discussion of Jervell's scholarship. 
can have destructive consequences, how the term can be used to manipulate and threaten, and how the uncontrolled and uncontrollable fear of the fearful can bring them to terrorise others in the name of their judgemental, fearsome and even bullying God. That is one reason why Waaijman (2002:318) adds that fear of God is intrinsically connected with love. Without love, fear becomes servile, impure, hateful and even deadly.

There are indeed dark moments in the spiritual journey of biblical authors in which they experienced the fear of God most acutely and which may bring them to dread a threatening, violent God. In its worst form, such fear creates deep psychological anxiety, hopelessness and feelings of helplessness, not to mention distance and hostility between people. At its best, though, it makes people acutely aware of their creatureliness, of being awesomely, but intimately involved, together with others, in a relationship with a Creator who powerfully reaches out to creation and humanity with providential compassion and love. At the same time it emphasised that God was completely different from and other than creation, not under control of human beings or never fully fathomed by the human intellect. Thus fear of God represents language that understands its own limitations, but at the same time language that reflects the experience that there is more to life than being part of the world and living one's own life for oneself. Loader underscored this when he linked fear of God with love, grace and hope - as was mentioned above. Fear in this sense lights up even brighter when it is contrasted with the darker side of biblical texts where more base emotions of fear are mooted.

\section{Acknowledgements \\ Competing interests}

The author declares that he has no financial or personal relationship(s) that may have inappropriately influenced him in writing this article.

\section{References}

Balz, H.R., 1965, s.v. 'Fear, фо $\beta \dot{c} \omega$ ktt', in G. Kittel, G. Friedrich \& G.W. Bromily (eds.), Theological Dictionary of the New Testament, Erdmans, Grand Rapids, vol. 9, pp. 186-216.

Balz, H.R., 1969, 'Furcht vor Gott: Überlegungen zu einem vergessenen Motiv biblischer Theologie', Evangelische Theologie 29, 626-644.

Barrett, C.K., 1998, Acts 1-14, T\&T Clark, London. (International Critical Commentary).

Becker, J., 1965, Gottesfurcht im Alten Testament, Pontifical Biblical Institute, Rome. (Analecta Biblica). Betz, H.D., 1983, 'The problem of apocalyptic genre in Greek and Hellenistic literature:
The case of the Oracle of Trophonius', in D. Hellholm (ed.), Apocalypticism in the Mediterranean World and the Near East, pp. 577-597, Mohr Siebeck, Tübingen.

Bovon, D., 2002, Luke 1: A commentary on the Gospel of Luke 1:1-9:50, Fortress, Minneapolis. (Hermeneia).

Bovon, F., 2009, Das Evangelium nach Lukas, Lk 19, 28-24:54, 4. Teilband, Neukirchener Verlag Neukirchen. (Evangelisch-Katholischer Kommentar zum Neuen Testament, III/4).

Brueggemann, W., 1994, The book of Exodus, Abingdon, Nashville. (New Interpreter's Bible, 1).

Brueggemann, W., 1997, Theology of the Old Testament: Testimony, dispute, advocacy, Fortress, Minneapolis.
Chambers, A., 2012, Exemplary life: A theology of church life in Acts, B\&H, Nashville.

Chaniotis, A., 2012, 'Unveiling emotions: Sources and methods for the study of emotions in the Greek world', in C. Angelos (ed.), Constructing the Fear of Gods: Epigraphic evidence from sanctuaries of Greece and Asia Minor, pp. 205-334, Steiner Verlag, Stuttgart.

Conzelmann, H., 1987, Acts of the apostles: A commentary on the acts of the apostles, transl. J. Limburg, A.T. Kraabel \& D.H. Juel, Fortress, Philadelphia. (Hermeneia).

Cross, F.M., 1973, Canaanite myth and Hebrew epic: Essays in the history of the religion of Israel, Harvard, Boston.

Deist, F.E., 1988, 'Die betekenissfeer van die leksikale morfeem /-y-r'-/ in die profetiese boeke van die Ou Testament' DLitt proefskrif, Departement Semitiese Tale, Stellenbosch Universiteit.

Dirks, W., 1976, Alte Wörter: Vier Kapitel zur Sprache der Frömmigkeit, Kaiser, München.

De Villiers, P.G.R., 2002a, 'Persecution in the book of Revelation' Acta Theologica 22, 47-70.

De Villiers, P.G.R., 2002b, 'Rome in the historical interpretation of Revelation', Acto Patristica et Byzantina 13, 120-142.

De Villiers, P.G.R., 2009, 'The understanding of violence in Oecumenius' Greek commentary on Revelatio', Acta Patristica et Byzantina 20, 232-245.

De Villiers, P.G.R., 2012a, 'Unmasking and challenging Evil. Exegetical perspectives on violence in Revelation 18', in P.G.R. de Villiers \& J.W. van Henten (eds.), Coping with violence in the New Testament, pp. 201-226, Brill, Leiden. http://dx.doi. org/10.1163/9789004221055_011, PMid:21484965

De Villiers, P.G.R., 2012b, 'Hermeneutical perspectives on violence in the New Testament', in P.G.R. de Villiers \& J.W. van Henten (eds.), Coping with violence in the New Testament, pp. 227-246, Brill, Leiden.http://dx.doi. org/10.1163/9789004221055_013, PMid:22257747

Englemann, E.E., 2009, 'Does fear remain in the Old Testament?', DTh dissertation, Department of Old Testament, Universität Wien.

Gray, P., 2003, Godly Fear: The Epistle to the Hebrews and Greco-Roman critiques of superstition, Society of Biblical Literature, Atlanta. (Society of Biblical Literature Academia Biblica, 16).

Jervell, J., 1998, Die Apostelgeschichte, Vandenhoeck \& Ruprecht, Göttingen. (Kritischexegetisches Kommentar, 3).

Johnson, L.T., 1992, The acts of the Apostles, The Liturgical Press, Collegeville.

Konstan, D., 2006, The emotions of the Ancient Greeks: Studies in Aristotle and classical literature, University of Toronto Press, Toronto. PMCid:PMC2648062

Kotze, Z., 2004, 'A cognitive linguistic approach to the emotion of anger in Hebrew Scriptures', HTS Teologiese Studies/Theological Studies 60(3), 843-863. http:// dx.doi.org/10.4102/hts.v60i3.622

Loader, J.A., 1986, Ecclesiastes: A practical commentary, Eerdmans, Grand Rapids.

Loader, J.A., 2001, 'Trembling, the best of being human: Aspects of anxiety in Israel', Old Testament Essays 14, 260-280.

Louw, J.P. \& Nida, E.A., 1989, 'Attitudes and emotions', in J.P. Louw \& E.A. Nida (eds.) Greek-English lexicon of the New Testament: Based on semantic Domains, United Bible Societies, New York, pp. 288-320.

MacMullen, R., 2006, Voting about God in early church councils, Yale University Press, New Haven. PMCid:PMC1479853

Nussbaum, M., 2012, New religious intolerance: Overcoming the politics of fear in an anxious age, Belknap Press, Cambridge, MA. http://dx.doi.org/10.4159/ an anxious age, Belknap
harvard.9780674065918

Otto, R., 1920, Das Heilige, Trewendt \& Granier, Breslau.

Pedersen, J., 1959, Israel. It life and culture, Oxford University Press, London.

Pesch, R., 1986, Die Apostelgeschichte (Apg 1-12), Einsiedeln, Zürich. (EvangelischKatholischer Kommentar zum Neuen Testament 5.1).

Plath, S., 1962, Furcht Gottes. Der Begriff ירא im Alten Testament, Calwer Verlag, Stuttgart. (Arbeiten zur Theologie, 2.2).

Renn, S.D., 2005, s.v. 'Phobos', in S.D. Renn (ed.), Expository Dictionary of Bible Words: Word Studies for key English Bible words based on the Hebrew and Greek Texts, Hendrickson Publishers, Grand Rapids, pp. 370-373.

Smith, J., 2011, Dialogues between faith and reason: The death and return of God in modern German thought, Cornell University Press, Ithaca.

Spurgeon, C.H., 1866, 'Future punishment a fearful thing', in Spurgeon Gems \& other treasures of God's truth, viewed 21 July 2013, from http://www.spurgeongems. org/vols10-12/chs682.pdf

Tyson, J.B., 1999, Luke, Judaism and the Scholars: Critical approaches to Luke-Acts, The University of South Carolina Press, Columbia.

Van der Horst, P.W., 2006, 'Philo of Alexandria on the wrath of God', in P.W. van der Horst (ed.), Jews and Christians in their Graeco-Roman context. Selected essays on Early Judaism, Samaritanism, Hellenism, and Christianity, pp. 128-133, Moh Siebeck, Tübingen. (Wissenschaftliche Untersuchungen zum Neuen Testament, 196)

Waaijman, K., 2002, Spirituality. Forms, foundations, methods, Peetsers, Louvain.

Willis, J.T., 2010, Yahweh and Moses in conflict: The role of Exodus 4:24-26 in the book of Exodus, Lang, Bern. 